\title{
Humanidades Médicas: para Quem e para Quê?
}

\author{
Cavalcante, Lígia Menezes; Leite, Álvaro Jorge Madeiro; Neves Filho, Almir de Castro; \\ Sidrim, Pedro Randal Pompeu; Silva, Luziane Santiago \\ Universidade Federal do Ceará — ligiammcc@yahoo.com.br
}

Introdução: a medicina é uma profissão que possui componentes científicos e humanísticos. Essa natureza dual permite considera-la como ciência e arte, e ao longo da história pode-se perceber que esses dois componentes em alguns momentos desenvolvem-se de forma integrada e em outros de forma a dar destaque a um componente específico. nos últimos anos, as humanidades médicas vem ganhando cada vez mais destaque nos currículos acadêmicos das escolas médicas como uma forma de superar o modelo biomédico reducionista que por muito tempo predominou no desenvolvimento da medicina. As humanidades médicas permitem integrar recursos das ciências humanas ao ensino da medicina a fim de ampliar a compreensão sobre o ser humano, seu sofrimento e seus sentimentos. Objetivos: Identificar o que os estudantes de medicina, professores e profissionais médicos buscam no estudo das humanidades médicas. Relacionar o ensinoaprendizagem de humanidades médicas com a relação médico-paciente e a prática médica. Entender como as humanidades médicas podem melhorar a qualidade do atendimento médico e tornar-se um meio de humanização da medicina. Métodos: a pesquisa desenvolvida foi do tipo exploratória-qualitativa e foi realizada durante um evento sobre humanidades médicas. Os dados foram coletados por intermédio de entrevista estruturada após o consentimento do entrevistado. As entrevistas foram gravadas, transcritas e analisadas. Foi possível entrevistar estudantes de medicina, médicos, profissionais da área da saúde, professores universitários e palestrantes do evento. Resultados: Foram destacados pelos entrevistados alguns motivos que os instigam a procurar as humanidades médicas, como: ampliar a compreensão sobre as relações humanas, compartilhar experiências e vivências da prática médica, preservar a sensibilidade que vai se perdendo ao longo do tempo, ter um momento de reflexão e insight sobre a própria profissão e a prática médica, integrar o saber científico com o saber humanístico, promover uma formação integral e desenvolver um olhar mais humanizado acerca do processo saúde-doença. Muitos alunos salientaram a carência das humanidades médicas no currículo acadêmico e evidenciaram a posição subordinada que o tema tem em relação ao conteúdo científico entre os estudantes, professores e profissionais médicos. Os entrevistados também relataram a importância do tema para o aprimoramento da relação médico-paciente, já que permite desenvolver a empatia e a compaixão. Conclusões: Integrar a formação científico a formação humana é um desafio. As humanidades médicas permitem a imersão de conteúdo humanístico na formação do profissional médico, respeitando a experiência de cada um e propiciando uma independência na preservação da sensibilidade. Profissionais que tiveram a oportunidade de ter contato com as humanidades médicas proporcionam um atendimento mais consciente e humanizado, beneficiando não somente a si próprios, mas também os pacientes.

Cavalcante, Lígia Menezes; Leite, Álvaro Jorge Madeiro; Neves Filho, Almir de Castro; Sidrim, Pedro Randal Pompeu; Silva, Luziane Santiago. Humanidades Médicas: para Quem e para Quê?. In: Anais do Congresso Internacional de Humanidades \& Humanização em Saúde [= Blucher Medical Proceedings, num.2, vol.1]. São Paulo: Editora Blucher, 2014. ISSN 2357-7282

DOI 10.5151/medpro-cihhs-10804 